\title{
EMPIRICAL ASSESSMENT OF THE GROWTH RATE OF MAIZE PRODUCTION IN THE PRE - SAP, SAP AND POST - SAP PERIODS IN NIGERIA
}

\author{
Oyinbo Oyakhilomen, Yusuf Dodo Emmanuel, Researchers \\ Department of Agricultural Economics and Rural Sociology \\ Ahmadu Bello University, Zaria, Nigeria \\ E-mail: saintoyas@yahoo.com
}

Received May 13, 2012

\begin{abstract}
This study was carried out to provide empirical evidence on the growth rates of maize production in three sub - periods in Nigeria namely pre - Structural Adjustment Programme period, Structural Adjustment Program period and post - Structural Adjustment Programme period. Secondary data on maize production in Nigeria during the Pre - Structural Adjustment Programme period (1970 to 1985), Structural Adjustment period (1986 to 1994) and post - Structural Adjustment Programme period (1995 to 2007) were employed in this study. A growth rate model was used to estimate the growth rates of maize in the three sub-periods. The results of the analysis showed that the instantaneous growth rates of maize production are $-0.1 \%, 5.7 \%$ and $2.4 \%$ and the compound rates of growth of maize production are $0.001 \%, 0.059 \%$ and $0.024 \%$ for the pre - Structural Adjustment Programme, Structural Adjustment Programme and post - Structural Adjustment Programme periods respectively. The higher compound growth rate of maize production in the Structural Adjustment Programme period implies that the policy reforms in the period was more effective in ensuring increased growth of maize production over that of other periods in Nigeria. Therefore, despite the myriads of problems associated with the programme in Nigeria, it was beneficial to maize production in Nigeria.
\end{abstract}

\section{KEY WORDS}

Maize; Biological development; Social sciences; Policies; Trade policies; Agricultural products; Economic growth; Economic policies; Economics.

Maize is a stable food crop for most subSaharan Africans of which Nigeria is inclusive with per capital kg/year of 40 (FAOSTAT, 2003). Despite the economic importance of maize to the teeming populace in Nigeria, it has not been produced to meet food and industrial needs of the country and this could be attributed to low productivity from maize farms or that farmers have not adopted improved technologies for maize production (Onu et al., 2010). The demand for maize sometimes outstrips supply as a result of the various domestic uses (Akande, 1994). Additionally, other factors like price fluctuation, diseases and pests, poor storage facilities have been associated with low maize production in the country(Ojo, 2003). In a bid to increase food production in Nigeria over the years, several policy reforms have been put in place by successive governments and one of such policy reforms in time past is the Structural Adjustment Programme (SAP) introduced in July 1986. The SAP aimed at facilitating economic growth as a means of jump-starting the economy towards sustainable economic growth and development. The objectives of the programme included reconstructing and diversifying the productive base of the economy, by reducing the dependence on oil and imports, laying a basis for sustaining noninflationary growth, making substantial progress towards fiscal and balance of payment viability, improving efficiency of the private sector's contribution to economic growth, through liberalized trade and privatization of public sector enterprises, devaluing the naira and reducing government deficits and these translated into specific policy measures in the agricultural sector such as abolition of commodity boards, privatization and commercialization of agricultural and agroindustrial enterprises (Mesike, et al., 2008), the removal of all government subsidies on food and other agricultural products, promotion of the production and export of non-traditional agricultural 
products, import restrictive measures on food and other locally produced agriculturally based raw materials, increase of the budgetary allocation to the system of agricultural development projects as a major instrument for agricultural development(Kajisa et al., 1997). The overall objective of implementing structural adjustment in the agricultural sector was to increase agricultural production and export of agricultural products and because of the relative importance of agriculture to the economy, this was supposed to contribute to improvement in the growth of the economy. The policy reforms in existence prior to the introduction of SAP and after the SAP period differs and therefore, the growth in agricultural production is expected to vary in the Pre SAP, SAP and Post - SAP periods in Nigeria. In view of the foregoing, this study was designed to provide an empirical information on the growth rates of maize production in Nigeria in the Pre SAP, SAP and Post - SAP periods which would be relevant for policy formulation, implementation and evaluation in Nigeria.

\section{MATERIALS AND METHODS}

This study made use of secondary data which were principally elicited from the database from the Statistical Bulletins and Annual Reports of the Central Bank of Nigeria (CBN) and also journal articles. The secondary data used for analysis was on maize output in Nigeria extending from 1970 to 1985 (Pre - SAP period), 1986 to 1994 (SAP period) and 1995 to 2007(Post SAP period) and therefore, data on three sub periods were utilized in this study.

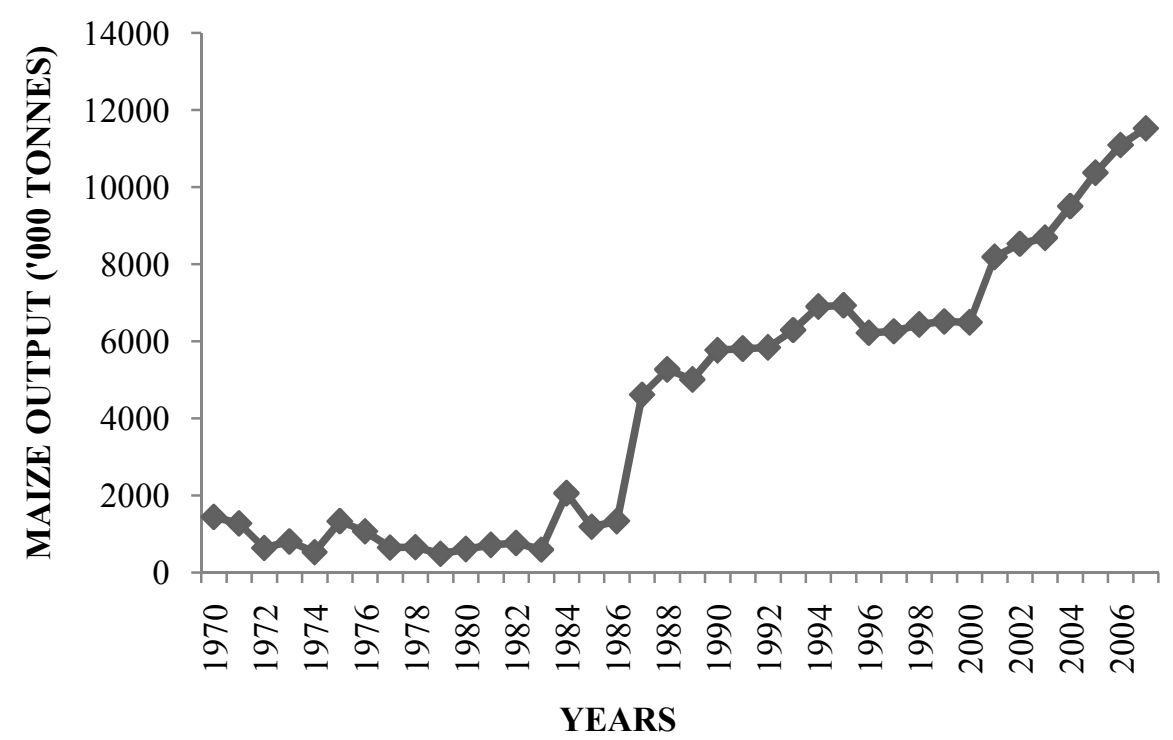

Figure 1 - Maize Production Trend in Nigeria (1970-2007)

\section{CONCEPTUAL FRAMEWORK}

The model employed in this study for the estimation of growth trend in maize output in Nigeria is the growth rate model adopted from (Gujarati, 2003). This model is a semi log model whose regressand is in logarithm form and the regressor is time variable which can take values from one, two, three to infinity. For descriptive purposes, the growth rate model is called a $\log -$ lin model and the slope coefficient of the model measures the constant proportional or relative change in the regressand for a given absolute change in the value of the regressor. This model has been used by Khalid and Burhan(2006).

Conceptual Framework. The model employed in this study for the estimation of growth trend in maize output in Nigeria is the growth rate model adopted from (Gujarati, 2003). This model is a semi log model whose regressand is in logarithm form and the regressor is time variable which can take values from one, two, three to infinity. For descriptive purposes, the growth rate model is called a log - lin model and the slope coefficient of the model measures the constant proportional or relative change in the regressand 
for a given absolute change in the value of the regressor. This model has been used by Khalid and Burhan(2006).

Model Specification. The compound interest formula is adopted for developing the model and is expressed as:

$$
\mathrm{Y}_{\mathrm{t}}=\mathrm{Y}_{0}(1+\mathrm{r})^{\mathrm{t}}
$$

Where:

$\mathrm{Y}_{\mathrm{t}}=$ Output of Maize(' 000 tonnes)

$\mathrm{Y}_{0}=$ Initial Value of Maize Output ('000 tonnes)

$r=$ Compound rate of growth of Maize output over time

$\mathrm{t}=$ Time trend (1970 to 1985,1986 to 1994 and 1995 to 2007 )

Taking the natural logarithm of equation (1), equation (2) was derived as:

Where:

$$
\ln Y_{t}=\ln Y_{0}+\operatorname{tln}(1+r)
$$

$\mathrm{b}_{0}=\ln \mathrm{Y}_{0}$

$\mathrm{b}_{1}=\ln (1+\mathrm{r})$

Equation (2) is rewritten as:

$$
\ln \mathrm{Y}_{\mathrm{t}}=\mathrm{b}_{0}+\mathrm{b}_{1} \mathrm{t}
$$

Adding disturbance term to equation (3), the explicit form of the model employed was derived as:

Where:

$$
\ln Y_{t}=b_{0}+b_{1} t+u_{t}
$$

$\mathrm{Y}_{\mathrm{t}}=$ Output of Maize ('000 tonnes) $\mathrm{t}=$ Time trend (1970 to 1985,1986 to 1994 and 1995 to 2007)

$\mathrm{b}_{0}=$ constant term

$\mathrm{b}_{1}=$ Coefficient of time variable

$\mathrm{u}_{\mathrm{t}}=$ Random term

After the estimation of equation (1), the compound rate of growth was computed as follows:

$$
r=\left(e^{b_{1}}-1\right)
$$

Where:

$r=$ compound rate of growth

$b_{1}=$ estimated coefficient from equation (1)

\section{RESULTS AND DISCUSSION}

The result in table 1 shows that time variable was significant in influencing output of maize at $5 \%$ and $1 \%$ in the SAP and post - SAP periods respectively and was insignificant in the pre - SAP period. In the estimated growth rate model, the slope coefficients of $-0.001,0.057$ and 0.024 for pre - SAP period, SAP period and post - SAP periods respectively measures relative change in output of maize for a given change in the value of time trend. By multiplying the relative change in maize output for pre - SAP period, SAP period and

\begin{tabular}{|c|c|c|c|}
\hline Variable & Coefficient & Standard Error & $\mathrm{t}$ - value \\
\hline \multicolumn{4}{|c|}{ PRE - SAP PERIOD } \\
\hline Constant $\left(b_{0}\right)$ & 5.449 & 20.152 & 0.270 \\
\hline Time $\left(b_{1}\right)$ & -0.001 & 0.010 & -0.125 \\
\hline R square & 0.001 & - & - \\
\hline \multicolumn{4}{|c|}{ SAP PERIOD } \\
\hline Constant $\left(b_{0}\right)$ & -109.449 & 40.739 & 2.687 \\
\hline Time $\left(b_{1}\right)$ & $0.057 * *$ & 0.020 & 2.777 \\
\hline R square & 0.520 & - & - \\
\hline \multicolumn{4}{|c|}{ POST - SAP PERIOD } \\
\hline Constant $\left(b_{0}\right)$ & -43.744 & 5.436 & 8.045 \\
\hline Time $\left(b_{1}\right)$ & $0.024 * * *$ & 0.003 & 8.763 \\
\hline R square & 0.870 & - & - \\
\hline
\end{tabular}
post - SAP periods respectively by hundred, we obtained the percentage change or the growth rate in maize output for an absolute change in time.

Table 1 - Estimated Regression of Growth Rate of Maize Production in Nigeria

$* * * \mathrm{P}<0.01, * * \mathrm{P}<0.05, * \mathrm{P}<0.1$

Pre - SAP period

Growth rate $=$ relative change $\times 100 ;$ Growth rate $=-0.001 \times 100 ;$ Growth rate $=-0.1 \%$

SAP Period

Growth rate $=$ relative change $\times 100 ;$ Growth rate $=0.057 \times 100 ;$ Growth rate $=5.7 \%$

Post - SAP Period

Growth rate $=$ relative change $\times 100 ;$ Growth rate $=0.024 \times 100 ;$ Growth rate $=2.4 \%$ 
The growth rates of $-0.1 \%, 5.7 \%$ and $2.4 \%$ for pre - SAP period, SAP period and post - SAP periods respectively implies that over the period, 1970 - 1985, 1986 - 1994 and 1995 - 2007, the output of maize in Nigeria increased at the rate of $-0.1 \%, 5.7 \%$ and $2.4 \%$ per annum. However the growth rate worked out are an instantaneous (at a point in time) rate of growth and not the compound (over period of time) rate of growth. Compound growth rates (r) were estimated from the instantaneous rates of growth, in that $-0.1 \%$, $5.7 \%$ and $2.4 \%$ are instantaneous growth rates:

$\ln (1+r)=b_{1}$ (as discussed in model specification)

$$
\begin{aligned}
& \ln (1+r)=b_{1} \\
& r=\text { Antilnb }_{1}-1 \\
& \mathrm{r}=\left(e^{b_{1}}-1\right) \\
& -\mathbf{S A P} \text { period } \\
& \mathrm{r}=\left(e^{-0.001}-1\right) \\
& \text { Compound rate of growth }(\mathrm{r})=-0.001 \%
\end{aligned}
$$

Pre - SAP period

\section{SAP Period}

$$
\begin{aligned}
& r=\left(e^{0.057}-1\right) \\
& \text { Compound rate of growth }(r)=0.059 \% \\
& - \text { SAP period } \\
& r=\left(e^{0.024}-1\right) \\
& \text { Compound rate of growth }(r)=0.024 \%
\end{aligned}
$$$$
\text { Post - SAP period }
$$

Therefore, the rate of growth of maize output in Nigeria per annum during the pre - SAP period, SAP period and post - SAP periods (instantaneous rates of growth) are of $-0.1 \%, 5.7 \%$ and $2.4 \%$ and the rate of growth of maize output in Nigeria over the periods $1970-1985,1986-$ 1994 and 1995 - 2007 (compound rates of growth) are $-0.001 \%, 0.059 \%$ and $0.024 \%$ respectively. It was observed that the compounded growth rate of maize output in Nigeria during the SAP era was higher than during the pre -SAP and post - SAP eras and also the compounded rate of growth was slightly higher than the instantaneous growth rate by 0.2 and this is attributed to the compounding effect. The implication of the growth rate of maize being higher in the SAP era as compared to the pre - SAP era and post - SAP era is that the policy reform of the SAP era was favourable in ensuring increased maize production in Nigeria and therefore, the notion that SAP was a complete failure is misleading. According to Ugwu and Kanu (2011),despite the policy measures in the SAP period, the agricultural sector did not register significant overall growth but the findings of this study shows that there was significant growth rate of maize production in Nigeria during the SAP era as against the pre SAP and post - SAP eras. This study agrees with NCEMA (2003) who noted that in spite of the mixed performance of Structural Adjustment Programme in the country, it is important to stress the continued relevance of its basic tenets to our social and economic situation now and in the future and therefore, calls for an in-depth analysis of the past reform programmes with a view to drawing lessons for future reforms.

\section{CONCLUSION}

The instantaneous growth rates and compound growth rates of maize production in the pre - SAP, SAP and post - SAP periods in Nigeria were estimated using a growth rate model. The results of the analysis showed that the instantaneous growth rates of maize production in $\mathrm{Ni}$ geria are $-0.1 \%, 5.7 \%$ and $2.4 \%$ for the pre SAP, SAP and post - SAP periods respectively and the compound rates of growth of maize production in Nigeria are $-0.001 \%, 0.059 \%$ and $0.024 \%$ for the pre - SAP, SAP and post - SAP periods respectively. The compound rate of growth of maize in the SAP era was found to be higher than that of the pre - SAP and post - SAP eras in Nigeria. From the findings of this study, it can be inferred that the policy reforms in the SAP era was effective in achieving increased production of maize relative to other policy reforms in the pre - SAP and post - SAP eras. 


\section{REFERENCES}

Akande, S.O. 1994. Comparative Cost and Return in Maize Production in Nigeria. Nigeria Institute for Social and Economic Research (NISER) individual Research Project Report, Ibadan: NISER.

Central Bank of Nigeria, 2007. Domestic Production, Consumption and Prices. Central Bank of Nigeria Statistical Bulletin, Volume 18.

Gujarati, D.N. and Porter, C. D. (2009). Basic Econometrics (5th Edition). McGrawHill, New York.

Kajisa, K., Mardia, M. and Boughton, D. (1997). Transformation versus stagnation in the oil palm industry: a comparison between Malaysia and Nigeria, Staff Paper No. 97-5 (East Lansing: Michigan State University).

Khalid, M. and Burhan, A. (2006). An Econometric Model for Forecasting Export of Kinnow fromPakistan. International Journal of Agriculture and Biology, 8(2): 459462.

Mesike, C.S., Giroh D.Y. and Owie, O.E.D (2008). Analyzing the Effect of Trade Liberalization Policy on Nigerian Rubber Industry. Journal of Agriculture \& Social Sciences, 4(3): 132-134.
National Centre for Economic Management and Administration, (2003). Structural Adjustment Programme in Nigeria: Causes, Processes and Outcomes. Revised Technical Proposal. : 1-17.

Nmadu, J. N. (2009). Effect of Changes in Some Macro-Economic Policies on Sorghum Economy in Nigeria between 1961 and 2005. Journal of Social Sciences, 20(3): 163-168.

Onuk E. G; Ogara I. M; Yahaya, H and Nannim, N. (2010). Economic Analysis of Maize Production in Mangu Local Government Area of Plateau State, Nigeria. PAT Journal, 6 (1): 1-11.

Ojo, S.O.(2000). Factor Productivity in Maize Production in Ondo state, Nigeria. Applied Tropical Agriculture,15(1): 57-63.

Ugwu, D.S. and Kanu, I. O. (2011). Effects of agricultural reforms on the agricultural sector in Nigeria. Journal of African Studies and Development, 4(2): 51-59. 